\title{
Authors' reply to: Letter to the Editor in response to 'Parental attachment and depressive symptoms in pregnancies complicated by twin-twin transfusion syndrome: a cohort study'
}

Fiona L. Mackie ${ }^{1 *}$, R. Katie Morris ${ }^{2,3}$ and Mark D. Kilby ${ }^{4,5}$

\begin{abstract}
In this correspondence we thank the authors for highlighting the importance of our work, and agree with the limitations they have raised regarding performing this study.
\end{abstract}

Keywords: Twin twin transfusion syndrome, Parental attachment, Anxiety, Fetoscopic laser ablation, Mental health

\section{Main text}

\section{Dear Editor}

We thank Rameh et al. [1] for highlighting the importance of our work [2]. The limitations of our study, as stated by Rameh et al. are mentioned in our published article. The need to interpret our findings of the postablation and postnatal questionnaires with caution due to the low numbers was highlighted in our article. We agree that future research should explore the additional potential associations with anxiety, coping styles in times of stress, the parent's own attachment style, and romantic attachment to their partner on parental attachment. Ideally these associations should be explored with validated assessment tools. Interviews with parents would give additional useful information and may improve follow-up data collection. Additionally future studies

This reply refers to the comment available at https://doi.org/10.1186/s12884021-03688-7.

* Correspondence: fionamackie@doctors.org.uk

'Department of Obstetrics and Gynaecology, Worcestershire Acute NHS

Trust, Royal Worcestershire Hospital, Charles Hastings Way, WR5 1DD Worcester, UK

Full list of author information is available at the end of the article should be performed in larger cohorts which would require collaboration between treatment centres. We hope that our study will improve patient care by increasing health care professional and patient awareness of the need to risk assess and screen mothers and fathers going through a pregnancy complicated by twin-twin transfusion syndrome for mental health problems, and consequently enabling additional psychological support where needed.

\section{Acknowledgements \\ Not applicable.}

Authors' contributions

FLM drafted the reply, RKM and MDK reviewed and revised and the reply. FLM, RKM and MDK have approved the reply.

\section{Funding}

Not applicable.

Availability of data and materials Not applicable.

\section{Declarations}

Ethics approval and consent to participate Not applicable. 


\section{Consent for publication}

Not applicable.

\section{Competing interests}

The authors declare that they have no competing interests.

\section{Author details}

'Department of Obstetrics and Gynaecology, Worcestershire Acute NHS Trust, Royal Worcestershire Hospital, Charles Hastings Way, WR5 1DD Worcester, UK. ${ }^{2}$ Institute of Applied Health Research, University of Birmingham, West Midlands, Edgbaston, UK. ${ }^{3}$ Fetal Medicine Centre, Birmingham Women's and Children's NHS Foundation Trust, Birmingham Women's Hospital, Mindelsohn Way, Edgbaston, UK. ${ }^{4}$ Institute of Metabolism and Systems Research, College of Medical and Dental Sciences, University of Birmingham, Birmingham, UK. ${ }^{5}$ Centre for Women's and Children's Health, Birmingham Health Partners, Birmingham, UK.

Received: 18 December 2020 Accepted: 1 March 2021

Published online: 22 March 2021

\section{References}

1. Rameh G, Tohme P, Abi-Habib R, Chalouhi GE. Letter to the Editor in response to 'Parental attachment and depressive symptoms in pregnancies complicated by twin-twin transfusion syndrome: a cohort study'. BMC Pregnancy Childbirth. 2021. https://doi.org/10.1186/s12884-021-03688-7.

2. Mackie FL, Pattison H, Jankovic J, Morris RK, Kilby MD. Parental attachment and depressive symptoms in pregnancies complicated by twin-twin transfusion syndrome: a cohort study. BMC Pregnancy Childbirth. 2020;20(1): 4

\section{Publisher's Note}

Springer Nature remains neutral with regard to jurisdictional claims in published maps and institutional affiliations.

- fast, convenient online submission

- thorough peer review by experienced researchers in your field

- rapid publication on acceptance

- support for research data, including large and complex data types

- gold Open Access which fosters wider collaboration and increased citations

- maximum visibility for your research: over $100 \mathrm{M}$ website views per year

At BMC, research is always in progress. 